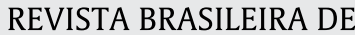

\section{Three new species of Bruggmanniella Tavares, 1909 (Diptera, Cecidomyiidae) from Brazil with a key to species}

\author{
Alene Ramos Rodrigues ${ }^{1 *}$ (D), Sheila Patrícia Carvalho-Fernandes ${ }^{1}$, \\ Valéria Cid Maia ${ }^{1}$, Lázaro Araújo Oliveira²
}

${ }^{1}$ Museu Nacional, Departamento de Entomologia, Rio de Janeiro, RJ, Brasil

${ }^{2}$ Universidade Federal de Minas Gerais, Ecologia Evolutiva E' Biodiversidade, Belo Horizonte, MG, Brasil

\section{A R T I C L E I N F O}

\section{Article history:}

Received 19 March 2019

Accepted 21 January 2020

Available online 16 March 2020

Associate Editor: Diana Grisales

\begin{abstract}
A B S T R A C T
Three new species, Bruggmanniella miconiae sp. nov., B. notatae sp. nov. and B. sideroxyli sp. nov., are described and illustrated. The new species are associated, respectively, with Miconia theaezans (Bonpl.) Cogn (Melastomataceae), Ocotea notata (Nees and Mart.) Mez (Lauraceae) and Sideroxylon obtusifolium (Roem. and Schult.) T. D. Penn. (Sapotaceae), respectively. The first one was collected in Dores do Indaiá city, Minas Gerais, Brazil; and the two others were collected in Mangaratiba city, Rio de Janeiro, Brazil. An illustrated key to the Bruggmanniella species is provided.
\end{abstract}

Keywords:

Cerrado

Gall midges

Neotropics

Restinga

Taxonomy

\section{Introduction}

Bruggmanniella Tavares, 1909 (Cecidomyiidae, Diptera) was described based in a single species that induces stem galls on Sorocea ilicifolia Miq. (Moraceae) in Rio Grande do Sul State, Brazil (Tavares, 1909). Since then, other species have been described, totalizing 11 species. Although the geographic distribution of the genus includes Southern Nearctic, Neotropical, and Oriental regions, Bruggmanniella is more diversified in the Neotropics, where it is represented by eight species, seven of them described from Brazil (Gagné and Jaschhof, 2017).

All species are gallers and they are associated with different plant organs (stems, twigs, flower buds, ovaries and fruits) of nine plant families: Anacardiaceae, Annonaceae, Celastraceae, Dilleniaceae, Fabaceae, Lauraceae, Malpighiaceae, Moraceae, and Sapotaceae (Gagné and Jaschhof, 2017).

The genus Bruggmanniella is characterized by having larva with four-toothed spatula; pupa with antennal horns, lack of frontal horns and presence of dorsal abdominal spines; adults with three-segmented palpus, simple tarsal claws, female eighth segment with cerci-like lobes and male with a completely divided tooth of gonostylus (Gagné,

\footnotetext{
* Corresponding author.

E-mail: alenerodrigues@yahoo.com.br (A.R. Rodrigues).
}

1994). Differing from the generic diagnosis, B. actinodaphnes Tokuda and Yukawa, 2006 and B. cinnamomi Tokuda and Yukawa, 2006 from Japan have two-toothed spatula, and B. bumeliae Felt, 1907 and B. oblita Tavares, 1920 from Brazil have three-toothed spatula.

Three new galling species from Brazil were obtained. The first induces galls on Miconia theaezans (Bonpl.) Cogn (Melastomataceae) (Fig. 1a), the second on Ocotea notata (Nees and Mart.) Mez (Lauraceae) (Fig. 1b), and the third on Sideroxylon obtusifolium (Roem. and Schult.) T. D. Penn. (Sapotaceae) (Fig. 1c). All host plant species are native of Brazil, and Ocotea notata is endemic, occurring exclusively in the Atlantic Forest (Jardim Botânico do Rio de Janeiro, 2018).

Miconia theaezans is a $2 \mathrm{~m}$ height shrub with widespread occurrence in South America. In Brazil, it is recorded in the States of Bahia, Goiás, Minas Gerais, Espírito Santo, Rio de Janeiro, São Paulo, Paraná, and Santa Catarina, in areas of Cerrado and Atlantic Forest (Goldenberg, 2013). Ocotea notata, popularly known as "canela-branca", is a medium-sized tree, widespread over the Brazilian Atlantic coast, being found mainly in sandy coastal plains, in the States of Pernambuco, Sergipe, Bahia, Minas Gerais, Espiríto Santo, and Rio de Janeiro (Garrett et al., 2012; Quinet et al., 2013). Sideroxylon obtusifolium, popularly known as 
"quixabeira", is a deciduous tree of $7-8 \mathrm{~m}$ height, with a dense and low crown (Silva et al., 2012). In Brazil, it occurs in Caatinga, sea coastal vegetation (from Ceará to Rio Grande do Sul), São Francisco Valley (Minas Gerais, Bahia, and Pernambuco) and Pantanal (State of Mato Grosso) (Paulino et al., 2011).

In this paper we described these new species and presented an illustrated key to Bruggmanniella species.

\section{Material and Methods}

Galls on Miconia theaezans (Melastomataceae) were collected in Porcos farm, Dores do Indaiá, Minas Gerais, Brazil (19² 30' 25.6" S and 45ㅇ 41' 8.6" W) in February 2009. Galls on Ocotea notate (Lauraceae) and Sideroxylon obtusifolium (Sapotaceae) were collected from April

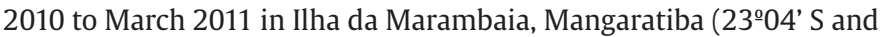
435ㅜㅇ' W), RJ.

Galled branches were removed from the host plants and taken to the laboratory for rearing of the gall midges. They were kept in plastic pots layered at the bottom with damp cotton and covered by fine mesh, being checked daily for emergence of adults. Immature insects were
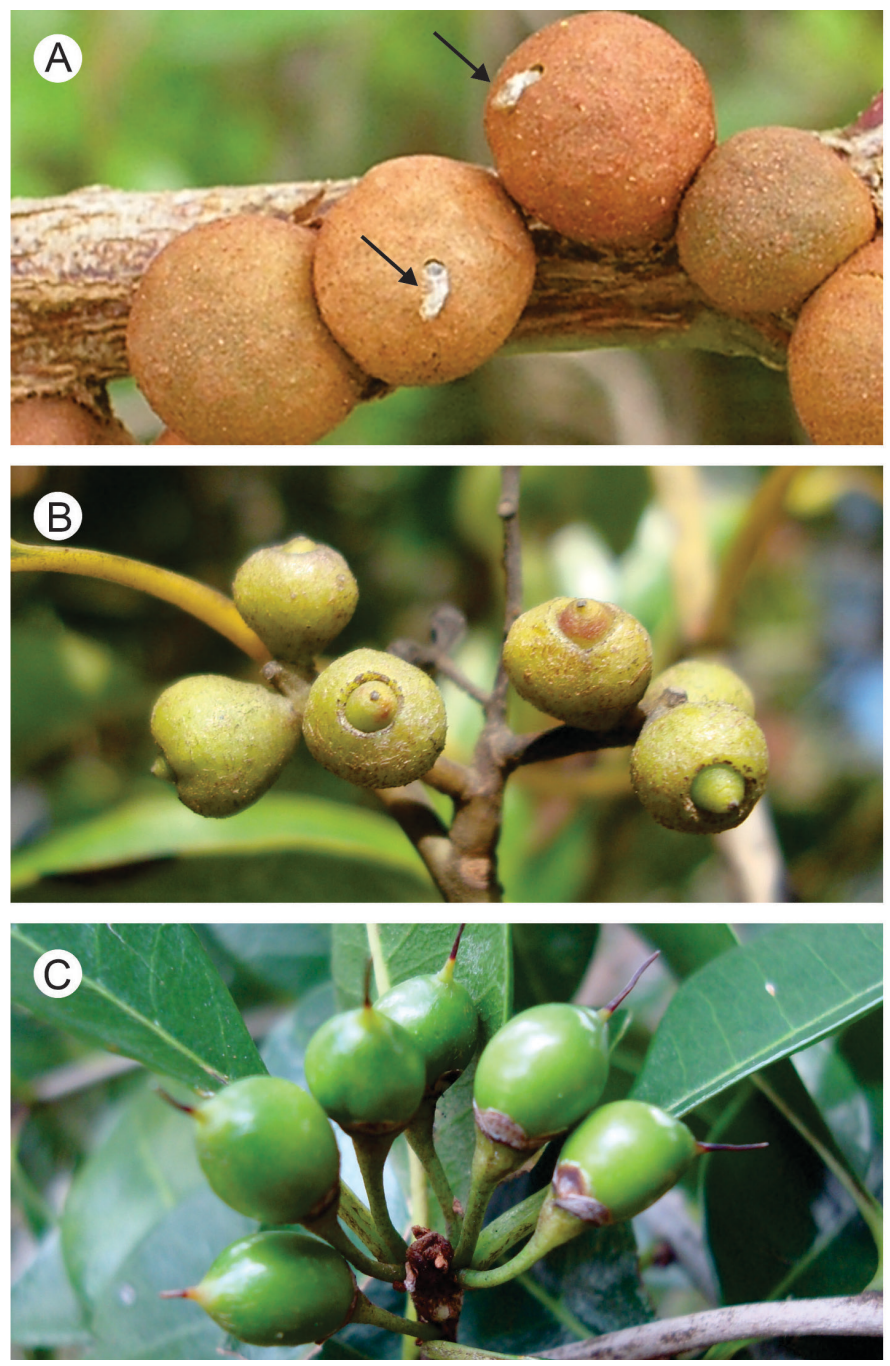

Figure 1. Galls of Bruggmanniella (Diptera, Cecidomyiidae). a) Stem gall on Miconia theaezans (Bonpl.) Cogn (Melastomataceae) induced by B. miconiae new species, arrows pointing pupal exuviae. b) Fruit gall on Ocotea notata (Nees and Mart.) Mez (Lauraceae) induced by $B$. notatae new species. c) Fruit gall on Sideroxylon obtusifolium (Roem. and Schult.) T. D. Penn. (Sapotaceae) induced by B. sideroxyli new species. obtained by dissecting some galls. All specimens were preserved in $70 \%$ ethanol.

The Cecidomyiidae specimens were mounted in slides following the methodology outlined in Gagné (1994), except for using butyl acetate instead of clove oil. All material is deposited in the Entomological Collection of Museu Nacional (MNRJ), Universidade Federal do Rio de Janeiro.

The field and laboratory work in Minas Gerais were carried out by L.A.O. and those in Rio de Janeiro by A.R.R.. The species descriptions and the key to Bruggmanniella species were elaborated by A.R.R., S.P.C.-F., and V.C.M.

Gagné et al. (2004) published the first key to the then six known Bruggmanniella species, which is herein updated to include the five recently described species and the three new species. It was elaborated based on the original descriptions of Bruggmanniella species and type material of B. byrsonimae Maia and Couri, 1992, B. doliocarpi Maia, 2010 and $B$. maytenuse Maia and Couri, 1992. The illustrations of the known species were redrawn from the original figures, except for the three species cited above, which were drawn from the type material. Some scales were not presented here because they were not provided in the original descriptions.

\section{Descriptions}

Bruggmanniella miconiae Carvalho-Fernandes, Maia \& Rodrigues new species

urn:Isid:zoobank.org:act:E271753A-DD62-421B-8516-44D563D5237C.

(Figs. 2 and 3)

Diagnosis. Palpus one-segmented, male hypoproct deeply bilobed, ovipositor rigid portion 1.6-1.9 length of $7^{\text {th }}$ sternite, antennal horns
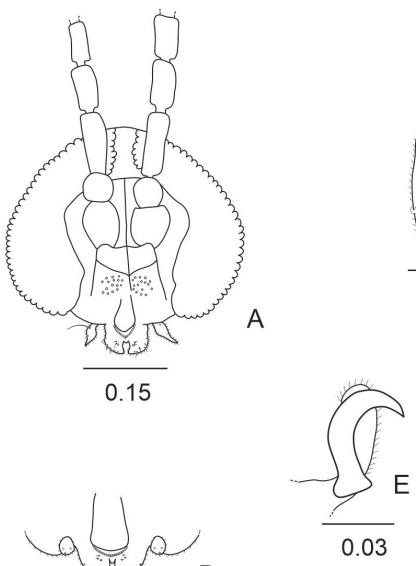

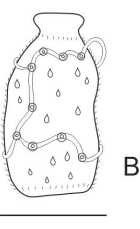

0.04

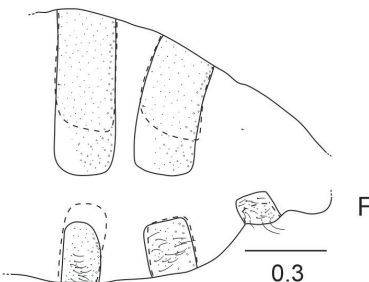

0.3
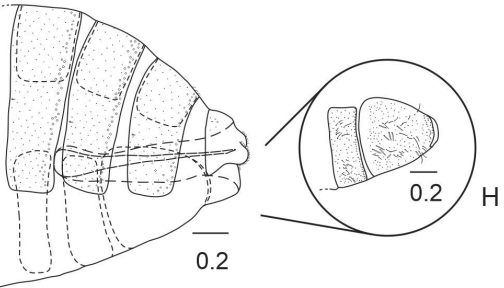

Figures 2. Bruggmanniella miconiae new species: a) female head, frontal view; b) male flagellomere 9 ; c) female flagellomere 5 ; d) male, ovoid palpus; e) female, tarsal claw and empodium of midleg; f) male, abdominal segments 6-8, lateral view; g) male, terminalia, dorsal view; h) female, abdominal segments 5-8, dorsolateral view, detail with sternites 6-7, ventral view. Scale bars in millimeters ( $\mathrm{mm})$. 

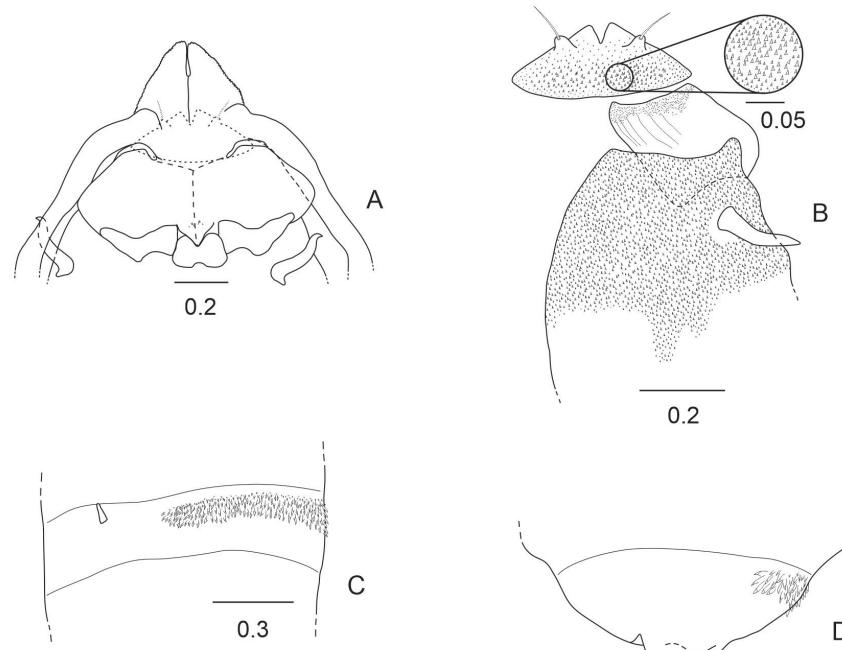

\section{C}
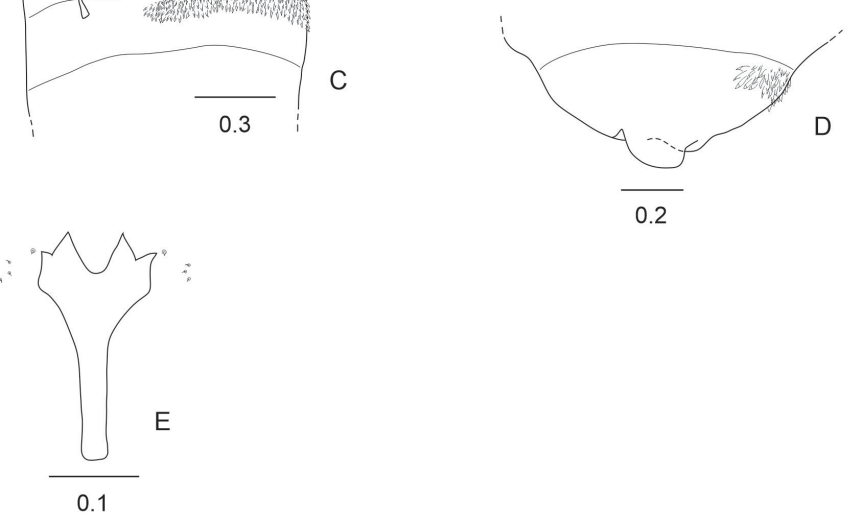

Figures 3. Bruggmanniella miconiae new species: a) pupa, cephalic region and prothoracic spiracle, frontal view; b) pupa, apical plate with integument detail and prothoracic right side, dorsal view; c) pupa, abdominal segment 5 with dorsal spines, dorsolateral view; d) pupa male, terminal segment, lateral view; e) larva, spatula, lateral and sternal papillae, ventral view. Scale bars in millimeters $(\mathrm{mm})$.

0.23-0.26 mm long with micro serrated margin, apical plate and prothoracic integument with short spines, spatula four-toothed.

Adult. Body length: $1.96-2.32 \mathrm{~mm}$ in male $(\mathrm{n}=3) ; 2.42-2.86 \mathrm{~mm}$ in female ( $n=3$, from head to eighth segment). Head (Fig. 2a): eyes totally separated in vertex, facets circular, closely approximated, except in the vertex. Antenna: scape obconic about 1.7 times length of the ovoid pedicel; flagellomeres cylindrical with bare necks in both sexes and the last one with an apical projection, first flagellomere $1.2-1.5$ times as long as the second one in male $(\mathrm{n}=4)$, and $1.3-1.6$ in female $(\mathrm{n}=4)$. Male flagellomeres (Fig. $2 \mathrm{~b}$ ) with slightly wavy circumfila and female flagellomeres (Fig. 2c) with two connected ring-like circumfila. Frontoclypeus with 30 - 34 setae. Labrum glossiform with rounded base, long attenuate. Hypopharynx triangular longer than labrum, apically. Labellae elongate-convex, each with three pairs of short mesal setae and few lateral setae. Palpi with one segment, ovoid in six specimens (five males and one female) (Fig. 2d) or claviform in three specimens (all females) (Fig. 2a). In a single female, the left palpus is claviform, while the right is ovoid.

Thorax: Wing length: $1.7-1.8 \mathrm{~mm}$ in male $(\mathrm{n}=4)$, and $1.9-2.1 \mathrm{~mm}$ in female $(n=4) ; R_{5}$ joining $C$ beyond wing apex. Anepimeron setose. Another pleura bare. Tarsal claws simple, curved beyond midlength, empodia long reaching bend in claws (Fig. 2e).

Male abdomen (Fig. 2f): $1^{\text {st }}-7^{\text {th }}$ tergites rectangular with a posterior row of setae, lateral row of setae, one anterior pair of trichoid sensilla, and elsewhere with scattered setulae. $8^{\text {th }}$ tergite not sclerotized and one anterior pair of trichoid sensilla. $1^{\text {st }}-6^{\text {th }}$ sternites rectangular with a posterior row of setae, lateral row of setae, some mesal setae, one anterior pair of trichoid sensilla, and elsewhere covered with setulae. $7^{\text {th }}$ sternite rectangular with a posterior row of setae, lateral setae, mesal setae distributed until proximal margin, one anterior pair of trichoid sensilla, and elsewhere covered with setulae. $8^{\text {th }}$ sternite rectangular, setose and covered with setulae. Terminalia (Fig. $2 \mathrm{~g}$ ): gonocoxite cylindrical, about 2.2 times length of gonostylus; gonostylus cylindrical with some long setae, gonostylus teeth triangular, in lateral view; cerci wide setulose with divergent lobes and with setae only apically; hypropoct slightly smaller than cerci, deeply bilobed, with two to three strongly setae apically and microsetulae, aedeagus cylindrical longer than hypropoct.

Female abdomen (Fig. $2 \mathrm{~h}$ ): $1^{\text {st }}-7^{\text {th }}$ tergites as in male. $8^{\text {th }}$ tergite rectangular with recess with scattered setulae. $1^{\text {st }}-6^{\text {th }}$ sternites as in male. $7^{\text {th }}$ sternite from 2.8 to 3.9 as long as sternite $6(n=4)$, strongly sclerotized, and completely covered with setae. $8^{\text {th }}$ sternite unsclerotized. Ovipositor: base pyriform, rigid portion 1.6 - 1.9 times as long as $7^{\text {th }}$ sternite $(n=4)$.

Pupa. Body length: $2.31-3.11 \mathrm{~mm}(\mathrm{n}=5)$. Cephalic region (Fig. 3a): antennal horns, with $0.23-0.26 \mathrm{~mm}$ of length and $0.09-0.12 \mathrm{~mm}$ of basal width, triangular, concave, with micro-serrated margin; cephalic setae $0.07 \mathrm{~mm}$ of length $(n=5)$; frontal region with two pairs of lower papillae, one setose and the other bare, lateral papillae not visible, upper facial margin thickened laterally, apical plate integument with numerous short spines (Fig. 3b). Prothoracic spiracle setiform (straight or curved), $0.14-0.17 \mathrm{~mm}$ of length $(\mathrm{n}=5)$ (Figs. $3 \mathrm{a}$ and $\mathrm{b}$ ). Prothoracic integument with numerous short spines (Fig. 3b). $3^{\text {rd }}-9^{\text {th }}$ abdominal segments with numerous dorsal spines (Fig. 3c). Abdominal spiracles conical on $3^{\text {rd }}-8^{\text {th }}$ segments, length of abdominal spiracle 5: $0.05-0.07 \mathrm{~mm}$ $(\mathrm{n}=5)$. Terminal abdominal segment bilobed in male (Fig. 3d) and rounded in females, with several dorsal spines.

Larva. white, body cylindrical, rounded anteriorly and tapered posteriorly, length: $2.3-2.4 \mathrm{~mm}(\mathrm{n}=2)$, integument grainy. Prothoracic spatula length, $0.25-0.31 \mathrm{~mm}(\mathrm{n}=5)$, width $0.12-0.14(\mathrm{n}=4)$, with 4 acute teeth, the inner ones longer than the outer ones, and stalk thin; three lateral setose papillae on each side of spatula (Fig. 3e). Terminal segment rounded without visible papillae.

Material examined. Holotype: Male, BRAZIL, Minas Gerais, Dores do Indaiá city, ii.2009, Oliveira, L. A. col.. Paratypes: same locality, data and collector: 4 males, 5 females, 4 pupal exuvia and 5 larvae.

Additional material examined: Same locality, data and collector: 4 males, 6 females, and 14 pupal exuvia.

Gall. on stems of $M$. theaezans, globoid, brown, glabrous, and one-chambered, with a single larva inside. The gall develops gregariously, resembling a grape bunch, (Fig. 1a). Pupation takes place inside the gall. The galls are induced at the beginning of raining season from November to December and its maturation occurs during from the end of January to February. When induced in young branches, these galls cause dryness and branch break.

Etymology. The specific name is the genitive of the host plant genus.

Remarks. This new species is unique in having eyes totally separated in the vertex; one-segmented palpus, ovipositor 1.6-1.9 as long as $7^{\text {th }}$ sternite. This is the first Bruggmanniella species associated with Melastomataceae.

Bruggmanniella notatae Rodrigues \& Maia new species

urn:Isid:zoobank.org:act:008CFD54-36DA-47AD-BBF8-FDFBE9CF4903. (Figs. 2 and 3)

Diagnosis. Palpus three-segmented, male hypoproct bilobed, ovipositor rigid portion 3.1 length of $7^{\text {th }}$ sternite, antennal horns 0.11-0.18 mm long with micro serrated margin, prothoracic integument grainy, spatula four-toothed.

Adult. Body length: $1.90 \mathrm{~mm}$ in male $(\mathrm{n}=1) ; 2.30-2.20 \mathrm{~mm}$ in female $(n=2)$. Head (Fig. $4 a)$ : eye connate in vertex, facets circular closely approximated. Antenna: scape obconic, 1.16 times length of pedicel; pedicel globose; flagellomeres cylindrical with bare necks in both sexes, first flagellomere equal in length to the second one in male 
$(\mathrm{n}=2)$, and 1.3 times longer in female $(\mathrm{n}=2)$. Male flagellomeres (Fig. $4 \mathrm{~b}$ ) with slightly wavy circumfila and female flagellomeres (Fig. 4c) with two connected ring-like circumfila. Frontoclypeus with at least 23 setae $(\mathrm{n}=1)$. Labrum elongated, apex triangular. Hypopharynx elongated, apex rounded, longer than labrum, apically. Labella riniform, with short mesal setae and few lateral setae. Palpi setose, three-segmented: first segment short and ovoid; second segment cylindrical, 2 times length of the first; third segment elongated and cylindrical, 2.0 times length of the second.

Thorax: Wing length: $1.75 \mathrm{~mm}$ in male $(\mathrm{n}=1)$, and $1.85-1.95 \mathrm{~mm}$ in female $(n=2) ; R_{5}$ joining $C$ beyond wing apex. Anepimeron setose. Another pleura bare. Tarsal claws simple, curved beyond $2 / 3$ basal, empodia as long as bending claws (Fig. 4d).

Male abdomen (Fig. 4e): $1^{\text {st }}-7^{\text {th }}$ tergites rectangular with a posterior row of setae, lateral row of setae, one anterior pair of trichoid sensilla, and elsewhere with scattered setulae. $8^{\text {th }}$ tergite not sclerotized with one anterior pair of trichoid sensilla. $1^{\text {st }}-7^{\text {th }}$ sternites rectangular with a posterior row of setae, lateral row of setae, some mesal setae, one anterior pair of trichoid sensilla, and elsewhere covered with setulae. $8^{\text {th }}$ sternite rectangular setose and covered with setulae. Terminalia (Fig. 4f): gonocoxite cylindrical setose, about 3.1 times length of gonostylus; gonostylus ovoid setose with some long setae, gonostylus teeth triangular, in lateral view; cerci wide setose, lobes ovoid divergent, with setae only apically; hypoproct setose slightly bilobed, with a pair of setae apically, slightly longer than cercus; aedeagus triangular narrow pointed at apex, almost as long as hypoproct.

Female abdomen (Fig. 4g): $1^{\text {st }}-7^{\text {th }}$ tergites rectangular with a posterior row of setae, lateral row of setae, one pair of trichoid sensilla.
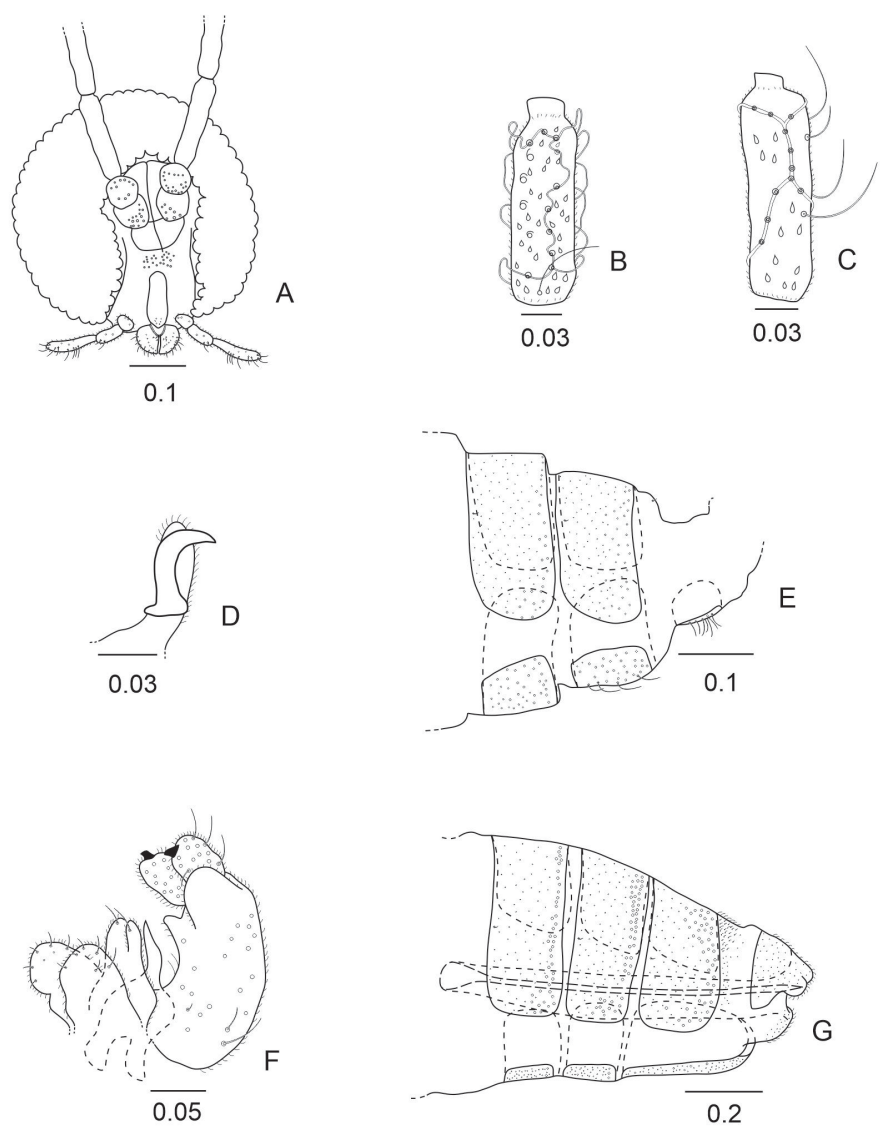

Figures 4. Bruggmanniella notatae new species: a) female head, frontal view; b) male flagellomere 4 ; c) female flagellomere 6 ; d) female tarsal claw and empodium of midleg; e) male, abdominal segments 6-8, dorsolateral view; f) male, terminalia, dorsolateral view; g) female, abdominal segments $5-8$, dorsolateral view. Scale bars in millimeters ( $\mathrm{mm}$ ). $8^{\text {th }}$ tergite with scattered setulae. $1^{\text {st }}-6^{\text {th }}$ sternites rectangular with a posterior row of setae, lateral row of setae, some mesal setae, one pair of trichoid sensilla, and elsewhere covered with setulae. $7^{\text {th }}$ sternite rectangular with apex rounded, about 2.2 times length of preceding sternite, rectangular, more sclerotized at distal margin, with scattered setae and two basal trichoid sensilla. $8^{\text {th }}$ sternite unsclerotized. Ovipositor: base tubular, rigid portion with 3.1 times length of $7^{\text {th }}$ sternite.

Pupa. Body length: $2.31-2.73 \mathrm{~mm}(\mathrm{n}=6)$. Cephalic region (Fig. 5a): antennal horns concave laterally, with micro-serrated margin, $0.11-0.18 \mathrm{~mm}$ of length $(\mathrm{n}=6)$; cephalic setae $0.075-0.085 \mathrm{~mm}$ of length $(n=6)$; two pairs of lower lateral papillae (one setose and the other bare); three pairs of lateral papillae (two setose and one bare); upper facial margin thickened laterally; apical plate integument smooth (Fig. 5b). Prothoracic spiracle cylindrical and elongated, slightly curved, $0.17-0.23 \mathrm{~mm}$ of length ( $n=6)$ (Figs. $5 \mathrm{a}$ and $b$ ). Prothoracic integument grainy as in the Fig. 5b. $3^{\text {rd }}-9^{\text {th }}$ abdominal segments with numerous dorsal spines (Fig. 5c). Abdominal spiracles conical on $4^{\text {th }}-7^{\text {th }}$ segments, length of abdominal spiracle 5: $0.03-0.05 \mathrm{~mm}(\mathrm{n}=6)$. Terminal segment bilobed in males (Fig. 5d) and rounded with a slightly reentrance in females, with dorsal spines.

Larva. white, body cylindrical, rounded anteriorly and tapered to end, length: $1.52 \mathrm{~mm}(\mathrm{n}=1)$, integument grainy. Prothoracic spatula length: $0.20 \mathrm{~mm}(\mathrm{n}=1)$, width: $0.07 \mathrm{~mm}(\mathrm{n}=1)$; four-toothed, internal teeth slightly longer than the external one; surrounding area pigmented; three setose lateral papillae at each side (Fig. 5e). Terminal segment rounded without visible papillae.

Material examined. Holotype: Male, BRAZIL, Rio de Janeiro, Mangaratiba city, Ilha da Marambaia, Armação beach, 21.xi.2010,
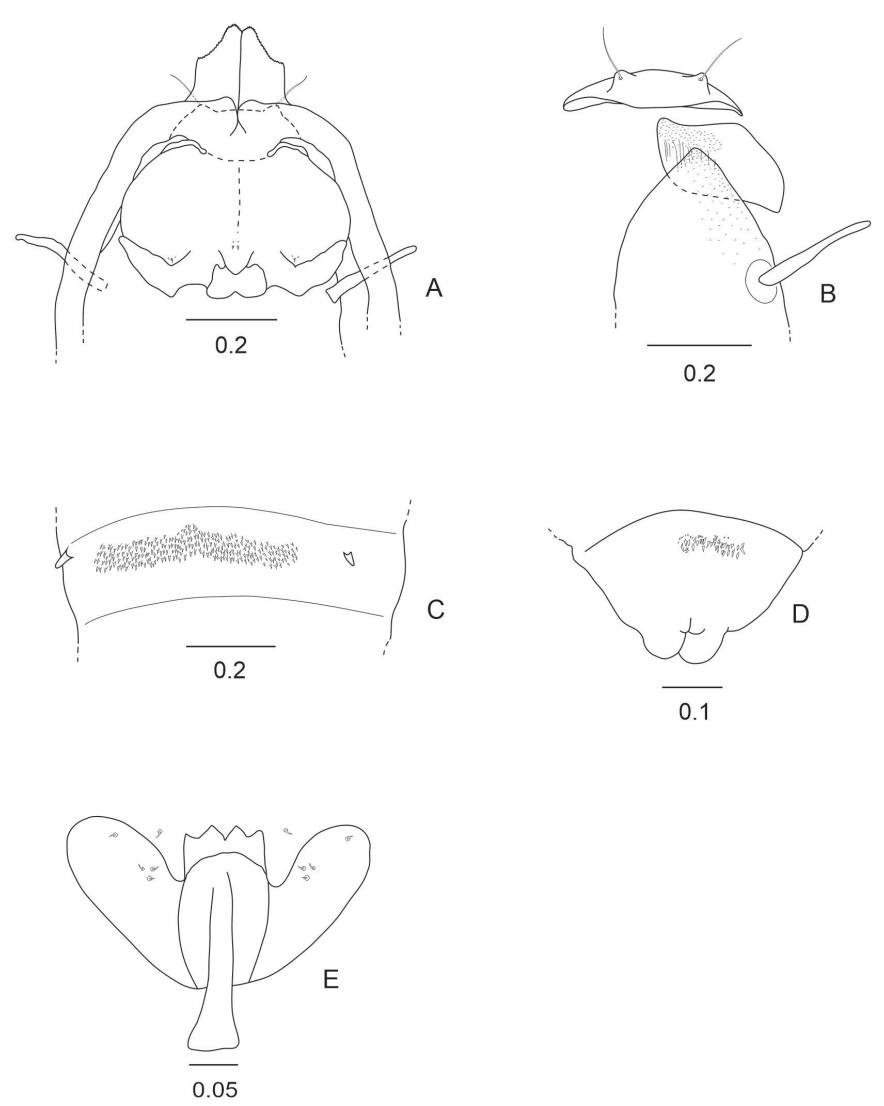

Figures 5. Bruggmanniella notatae new species: a) pupa, cephalic region and prothoracic spiracle, frontal view; b) pupa, apical plate and prothoracic right side, dorsal view; c) pupa, abdominal segment 5 with dorsal spines, dorsal view; d) pupa male, terminal segment, dorsal view; e) larva, spatula, sternal and lateral papillae, ventral view. Scale bars in millimeters ( $\mathrm{mm}$ ). 
Rodrigues, A. R. col.. Paratypes: same locality, data and collector: 2 females, 1 pupa, 5 pupal exuvia, and 1 larva.

Gall. on fruits of Ocotea notata (Lauraceae), ovoid, yellow-green, glabrous, one-chambered, with a single larva inside, pupation in the gall (Fig. 1b). Fruit with gall similar to healthy fruit. Occurrence from October to December of 2010.

Etymology. The specific name is the genitive of the host plant species.

Remarks. Bruggmanniella. notatae sp. nov. and B. persae Gagné, 2004 are unique among the other congeneric species in having larva with sclerotized area around the prothoracic spatula, but the former differs by having prothoracic spatula with all teeth acute and pupal antennal horns strongly concave laterally, while the latter has the prothoracic spatula with mesal teeth less acute than the lateral and pupal antennal horns strongly concave laterally.

\section{Bruggmanniella sideroxyli Rodrigues \& Maia new species}

urn:Isid:zoobank.org:act:959F93C7-C2BC-4C0A-936D-9ECFC08D1F1B

(Figs. 6 and 7)

Diagnosis. Palpus three-segmented, flagellomeres with striated short necks, male hypoproct deeply bilobed, ovipositor rigid portion 2.2-3.0 length of $7^{\text {th }}$ sternite, antennal horns $0.21-0.26 \mathrm{~mm}$ long with micro serrated margin, apical plate rough and prothoracic integument rough, spatula four-toothed.

Adult. Body length: $2.10-2.88 \mathrm{~mm}$ in male $(\mathrm{n}=2) ; 2.47-2.78 \mathrm{~mm}$ in female $(n=3)$. Head (Fig. $6 a)$ : eye connate in vertex, facets circular closely approximated. Antenna: scape obconic, 1.4 times length of pedicel; pedicel globose; flagellomeres cylindrical with striated short necks in both sexes, first flagellomere equal in length to the second one in male $(n=2)$, and $1.2-1.4$ times longer in female $(n=2)$. Male
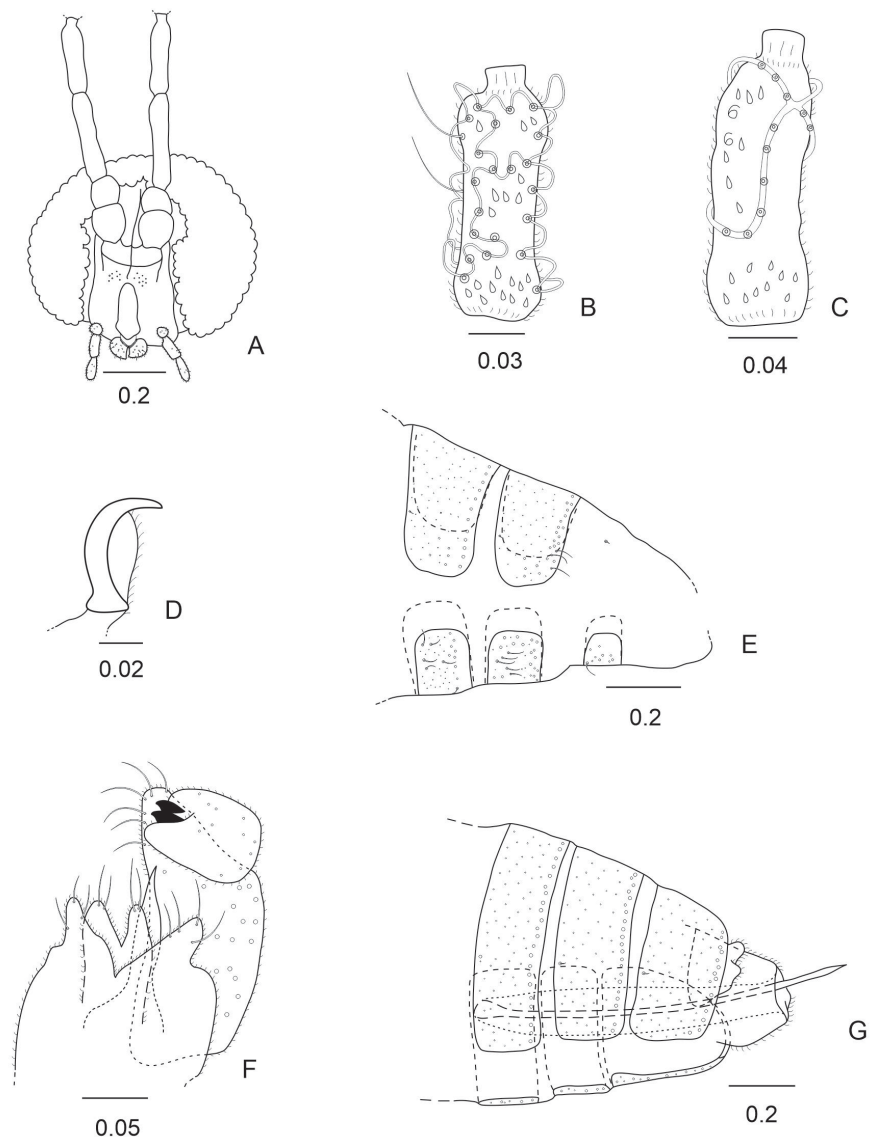

Figures 6. Bruggmanniella sideroxylinew species: a) female head, frontal view; b) male flagellomere 3 ; c) female flagellomere 4 ; d) male, claw and empodium of midleg; e) male, abdominal segments 6 - 8, lateral view; f) male, terminalia, dorsal view; g) female, abdominal segments 5 - 8, dorsolateral view. Scale bars in millimeters (mm). flagellomeres (Fig. 6b) with slightly wavy circumfila, female flagellomeres (Fig. 6c) with two connected ring-like circumfila. Frontoclypeus with $17-22$ setae $(n=3)$. Labrum elongated, apex triangular. Hypopharynx elongated, apex triangular, longer than labrum, apically. Labella triangular, each with three short mesal setae and few lateral setae. Palpi setose three-segmented: first segment short and ovoid; second segment cylindrical; third segment elongated and cylindrical, as long as the second.

Thorax: Wing length: male with $1.60-1.82 \mathrm{~mm}(\mathrm{n}=3)$; female with $2.21-2.27 \mathrm{~mm}(\mathrm{n}=3) ; \mathrm{R}_{5}$ joining $\mathrm{C}$ beyond wing apex. Anepimeron setose. Another pleura bare. Tarsal claws simple, curved beyond midlength, empodia almost as long as bending claws (Fig. 6d).

Male abdomen (Fig. 6e): $1^{\text {st }}-7^{\text {th }}$ tergites rectangular with a posterior row of setae, lateral row of setae, one pair of trichoid sensilla, and elsewhere with scattered setulae. $8^{\text {th }}$ tergite not sclerotized with one pair of trichoid sensilla. $1^{\text {st }}-7^{\text {th }}$ sternites rectangular with a posterior row of setae, lateral row of setae, some mesal setae, one anterior pair of trichoid sensilla, and elsewhere covered with setulae. $8^{\text {th }}$ sternite rectangular setose and covered with setulae, with one anterior pair of trichoid sensilla. Terminalia (Fig. 6f): gonocoxite cylindrical with setae and microsetae, about 2.8 times length of gonostylus; gonostylus ovoid with short setae and microsetae, apical teeth triangular, slightly askew in lateral view; cerci narrow setulose with triangular lobes, slightly longer than hypoproct; hypoproct deeply bilobed, with setae and microsetulae; aedeagus narrow pointed at apex, longer than cerci.

Female abdomen (Fig. $6 g$ ): $1^{\text {st }}-7^{\text {th }}$ tergites rectangular with a posterior row of setae, lateral row of setae, one anterior pair of trichoid sensilla, and elsewhere with scattered setulae. $8^{\text {th }}$ tergite with scattered
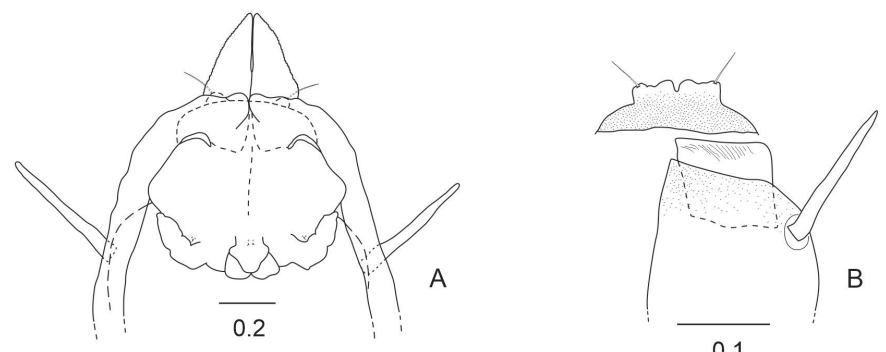

0.1
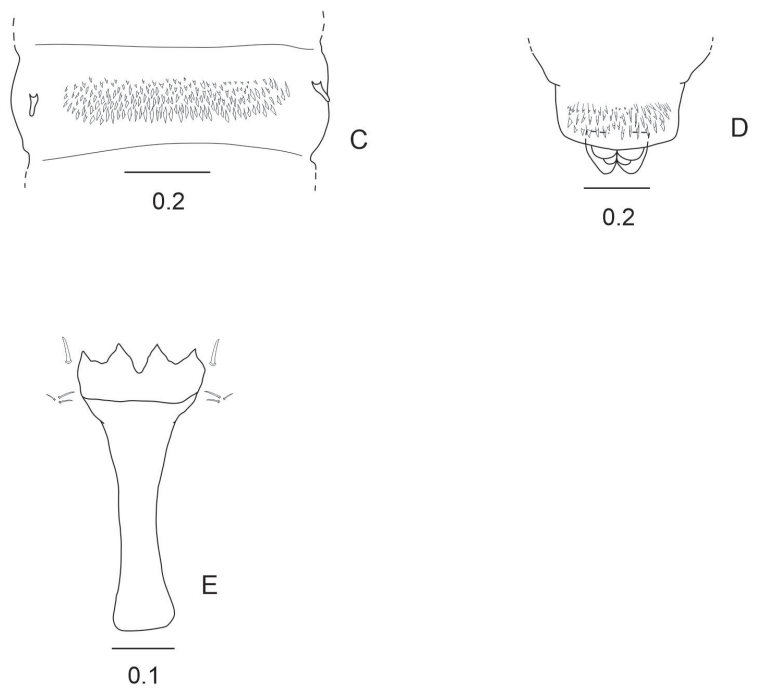

Figures 7. Bruggmanniella sideroxyli new species: a) pupa, cephalic region and prothoracic spiracle, frontal view; b) pupa, apical plate and prothoracic right side, dorsal view; c) pupa, abdominal segment 5 with dorsal spines, dorsal view; d) pupa, terminal segment, dorsal view; e) larva, spatula, sternal and lateral papillae, ventral view. Scale bars in millimeters ( $\mathrm{mm})$. 
setulae. $1^{\text {st }}-6^{\text {th }}$ sternites rectangular with a posterior row of setae, lateral row of setae, some mesal setae, one anterior pair of trichoid sensilla, and elsewhere covered with setulae. $7^{\text {th }}$ sternite rectangular with apex rounded, about $2.04-2.12$ length of preceding sternite, rectangular, more sclerotized at distal margin, with scattered setae and one anterior pair of trichoid sensilla. $8^{\text {th }}$ sternite unsclerotized. Ovipositor: base pyriform, rigid portion with 2.2 - 3.0 times length of $7^{\text {th }}$ sternite.

Pupa. Body length: $2.95-3.36 \mathrm{~mm}(\mathrm{n}=3)$. Cephalic region (Fig. 7a): antennal horns, triangular with micro-serrated margin, $0.21-0.26 \mathrm{~mm}$ of length ( $n=3)$; cephalic setae $0.07-0.10 \mathrm{~mm}$ of length $(n=3)$; two pairs of lower lateral papillae (one setose and the other bare); three pairs of lateral papillae (two setose and one bare); upper facial margin thickened laterally; apical plate integument rough (Fig. 7b). Prothoracic spiracle cylindrical, elongated and straight, $0.32-0.35 \mathrm{~mm}$ of length $(n=3)$ (Figs. 7a and b). Prothoracic integument grainy as in the Fig. 7b. $3^{\text {rd }}-9^{\text {th }}$ abdominal segments with dorsal spines (Fig. 7c), abdominal spiracles conical on $4^{\text {th }}-6^{\text {th }}$ segments, length of abdominal spiracle 5 : $0.05-0.06 \mathrm{~mm}(\mathrm{n}=3)$. Terminal segment bilobed in males (Fig. $7 \mathrm{~d}$ ) and rounded in females, with numerous dorsal spines.

Larva. white, body cylindrical, rounded anteriorly and tapered to end, length: $2.00-2.18 \mathrm{~mm}(\mathrm{n}=3)$, integument grainy. Prothoracic spatula length: $0.26-0.32 \mathrm{~mm}(\mathrm{n}=3)$, width: $0.11-0.13 \mathrm{~mm}(\mathrm{n}=3)$; four-toothed, internal teeth slightly larger than the external ones; stalk less sclerotized; three lateral papillae at each side with long setae; sternal papillae longer and stronger (Fig. 7e). Terminal segment rounded, without visible papillae.

Material examined. Holotype: Male, BRAZIL, Rio de Janeiro, Mangaratiba city, Ilha da Marambaia, Armação beach, 25.vii.2010, Rodrigues, A. R. col.. Paratypes: same locality, data and collector: 7 females, and 9 pupal exuvia. Paratypes: same collector: 1 female, 5 pupae and 5 larvae, Caju beach, 25.vii.2010. Paratypes: same collector: 2 males, Caju beach, 21.vi.2010.

Gall. on fruits of S. obtusifolium, ovoid, green, glabrous, multi-chambered, with a single larva inside each chamber, pupation in the gall (Fig. 1c). Fruit with gall similar to healthy fruit. Occurrence from June to August, and from October to November of 2010.

Etymology. The specific name is the genitive of the host plant genus.

Remarks. The new species is unique in presenting antennal flagellomeres with striated necks (adults) and prothoracic spatula with long and strong setiform sternal papillae (larva). This is the first record of galling insect associated with $S$. obtusifolium.

\section{Discussion}

The differences among the three new species described here and other Bruggmanniella species are found in the key. It is notable that Bruggmanniella species does not occur on leaves. They induce galls on stems (B. braziliensis Tavares, 1909; B. doliocarpi; B. duguetiae Urso-Guimarães and Amorim, 2004; B. actinodaphnes; B. cinnamomi; $B$. oblita and $B$. miconiae, new species), fruits ( $B$. persae Gagné et al., 2004; $B$. maytenuse; $B$. notatae, new species and $B$. sideroxyli, new species), twigs ( $B$. bumeliae), ovaries ( $B$. ingae Urso-Guimarães and Amorim, 2004), and flower buds (B. byrsonimae).

B. miconiae sp. nov. is morphologically similar to $B$. duguetiae. Both species have four-toothed spatula (larva), antennal horns minutely serrated (pupa), and eyes separate in vertex (adult), but they differ mainly by the palpi (one-segmented in the former and three-segmented in the latter) and length of female flagellomeres (conspicuously shorter in B. miconiae than in B. duguetiae).

$B$. notatae sp. nov. is morphologically similar to $B$. persae while $B$. sideroxylisp. nov. is morphologically similar to $B$. maytenuse. These four species have a long four-toothed spatula, antennal horns minutely serrated (pupa), and eyes connected in vertex (adult). Additionally, only $B$. notatae sp. nov. and $B$. persae have spatula with pigmented surrounding area. Nevertheless, $B$. notatae sp. nov. differs from $B$. persae by the spatula teeth (larva) and antennal horns shape (pupa). While in $B$. notatae sp. nov., all teeth are equally acute and the antennal projection is highly convex, in $B$. persae the outer teeth are more acute than mesal ones and the antennal projection is slightly convex. $B$. sideroxyli $\mathrm{sp}$. nov. can be distinguishable from $B$. maytenuse due to the shape of the antennal horns (convex laterally only in the latter) and relative length of spatula teeth (mesal teeth slightly longer than the lateral ones in B. sideroxyli and conspicuously longer than those in B. maytenuse).

\section{Key to Bruggmanniella species}

1. Larval spatula with four apical teeth (Fig. 3e)..................................... 2

- Larval spatula with less than four apical teeth (Fig. 8a)................ 11

2. Pupal antennal horn, coarsely serrate (Fig. 8b)................................. 3

Pupal antennal horn, minutely serrate (Fig. 7a) ................................. 5

3. Empodia longer than bend tarsal claws (Fig. 8c), on Sorocea ilicicola (Moraceae), Brazil.................................... B. braziliensis Tavares, 1909 Refs.: Tavares (1909); Möhn (1963)

- Empodia shorter than or equal to bend tarsal claws, on other plants ............................................................................................................ 4

4. Empodia shorter than bend tarsal claws, female flagellomeres not wavy (Fig. 8d), ovary galls on Inga edulis (Fabaceae), Brazil........................... B. ingae Urso-Guimarães and Amorim, 2004 Ref.: Urso-Guimarães and Amorim (2004)

- Empodia equal in length of bend tarsal claws, female flagellomeres wavy (Fig. 8e), flower bud galls on Byrsonima sericea(Malpighiaceae), Brazil......................................... b. byrsonimae Maia and Couri, 1992 Refs.: Maia et al. (1992); Maia (2001)

5. Eyes of adult connected in vertex (Fig. 4a).........................................6

Eyes of adult separated in vertex (Fig. 2a)........................................ 10

6. Larval spatula short, with a large and short shaft (Fig. 8f), male hypoproct bilobed, on Doliocarpus dentatus (Dilleniaceae), Brazil................................................................ B. doliocarpi Maia, 2010 Ref.: Maia et al. (2010)

- Larval spatula long, with a not large and long shaft (Fig. 8g), on other plants .......................................................................................... 7

7. Larval spatula with pigmented surrounding area (Fig. 5e)............ 8

- Larval spatula with not pigmented surrounding area (Fig. 7e)....9

8. Larval spatula with all teeth acute (Fig. 5e), pupa with antennal horns, highly concave (Fig. 5a), fruit galls on Ocotea notata (Lauraceae), Brazil.................................................................. notatae new species Larval spatula with lateral teeth more acute than mesal ones (Fig. 8g), pupa with antennal horns slightly concave (Fig. 8h), on Persea americana (Lauraceae), Colombia and Costa Rica.

B. perseae Gagné, 2004

Ref.: Gagné et al. (2004)

9. Pupal antennal horns narrow at base, slightly tapering (Fig. 8i), larval spatula with mesal teeth conspicuously longer than the lateral ones (Fig. 9a), fruit galls on Maytenus obtusifolia (Celastraceae), Brazil B. maytenuse Maia and Couri, 1992 Refs.: Maia et al. (1992); Maia (1999)

- Pupal antennal horns wide at base, strongly tapering (Fig. 7a), larval spatula with mesal teeth slightly longer than the lateral ones (Fig. 7e), on Sideroxylon obtusifolium (Sapotaceae), Brazil... B. sideroxyli new species

10. Eyes of adult slightly separate in vertex (Fig. 9b), palpus three-segmented (Fig. 9b), stem galls on Duguetia furfuracea (Annonaceae), BrazilB. duguetiaeUrso-Guimarães and Amorim, 2004 


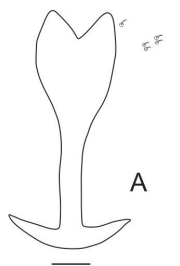

0.1
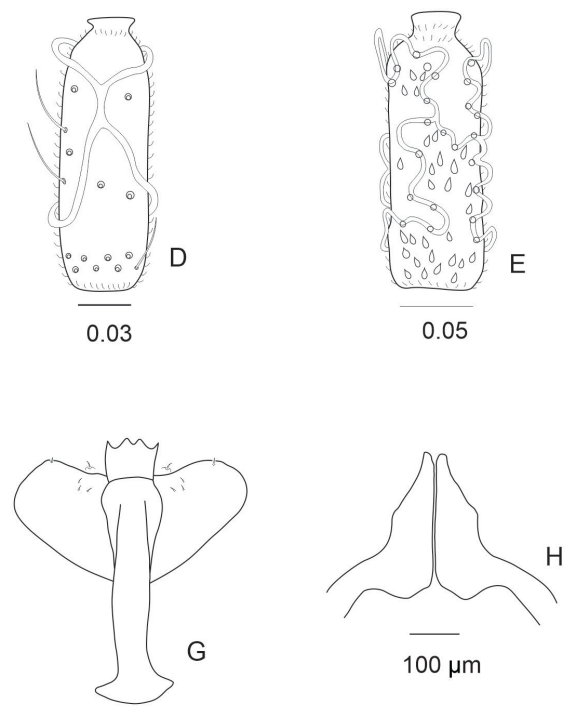

Figure 8. a) Bruggmanniella cinnamomi, larva, prothoracic spatula, sternal and lateral papillae, ventral view, from Tokuda and Yukawa (2006). b) B. byrsonimae, pupal apices of antennal horns, frontal view. c) B. braziliensis, tarsal claw and empodium, from Tavares (1909), without scale bar. d-e) female fifth flagellomere: d) B. ingae, from Urso-Guimarães and Amorim (2004); e) B. byrsonimae.f-g) larva, prothoracic spatula, sternal and lateral papillae, ventral view (original figures without scale bar): f) B. doliocarpi; g) B. persae, and pleural papillae, from Gagné et al. (2004). h-i) pupal apices of antennal horns, frontal view: h) B. persae, from Gagné et al. (2004); i) B. maytenuse. Scale bars in mm, except for figure $h$ (in $\mu \mathrm{m})$.

Ref.: Urso-Guimarães and Amorim (2004)

- Eyes of adult widely separated in vertex (Fig. 2a), palpus one-segmented (Fig. 2a), on Miconia theaezans (Melasomataceae), Brazil B. miconiae new species

11. Larval spatula with two teeth (Fig. 8a) ....12

- $\quad$ Larval spatula with three teeth (Fig. 9c) .13

12. Male hypoproct with U-shaped emargination (Fig. 9d), pupal antennal horns with three lateral teeth (Fig. 9e), stem galls on Actinodaphne lancifolia (Lauraceae), Japan B. actinodaphnesTokuda and Yukawa, 2006 Ref.: Tokuda and Yukawa (2006)

- Male hypoproct barely emarginated (Fig. 9f), pupal antennal horns without additional projection (Fig. 9g), on Cinnamomum japonicum (Lauraceae), Japan............ B. cinnamomi Tokuda and Yukawa, 2006 Ref.: Tokuda and Yukawa (2006)

13. Pupal antennal horns twice as long as widest diameter (Fig. 9h), twig galls on Bumelia lanuginosa (Sapotaceae), USA and Mexico.

B. bumeliae Felt, 1907

Refs.: Felt (1907); Gagné (1994)

- Pupal antennal horns approximately as long as widest diameter (Fig. 9i), stem galls on Schinus sp. (Anacardiaceae), Brazil B. oblita Tavares, 1920

Refs.: Tavares (1920); Möhn (1961)
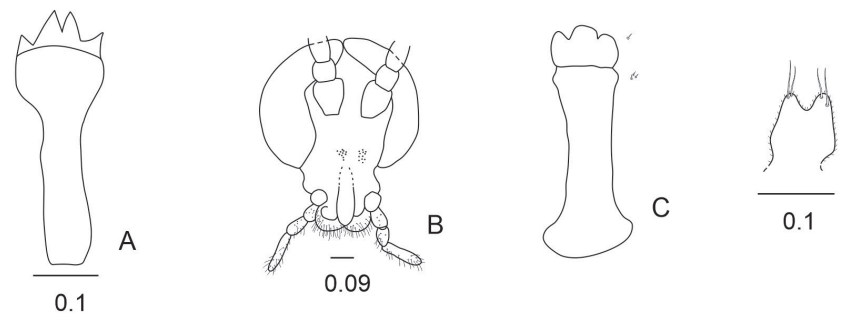

D
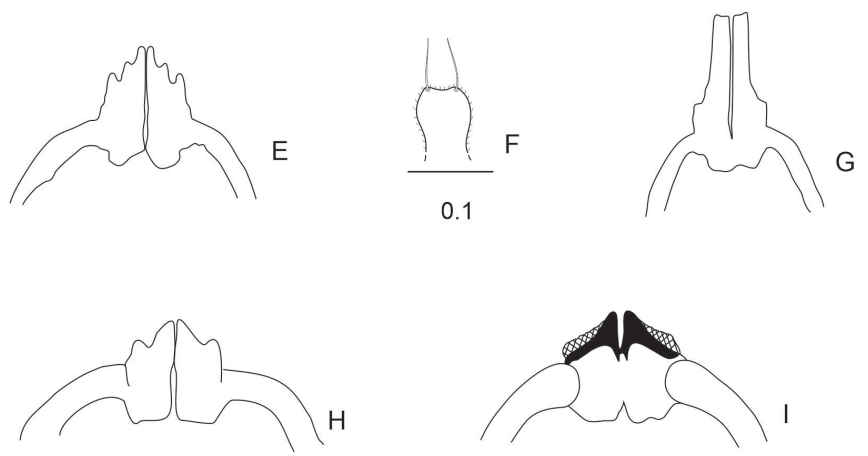

Figures 9. a) B. maytenuse, larva, prothoracic spatula, ventral view. b) B. duguetiae, adult head, frontal view, from Urso-Guimarães and Amorim (2004). c) B. bumeliae, larva, prothoracic spatula, sternal and lateral papillae, ventral view, from Felt (1907). d-e) B. actinodaphnes, from Tokuda and Yukawa (2006): d) male hypoproct, dorsal view; e) pupal apices of antennal horns, frontal view. f) B. cinnamomi, male hypoproct, dorsal view, from Tokuda and Yukawa (2006). g-i) pupal apices of antennal horns, frontal view: g) B. cinnamomi, from Tokuda and Yukawa (2006); h) B. bumeliae, from Felt (1907); i) B. oblita, from Tavares (1920). Figures c, e, g-i without scales in the original drawings. Scale bars in $\mathrm{mm}$.

\section{Acknowledgments}

To Conselho Nacional de Desenvolvimento Científico e Tecnológico (CNPq) for financial support and Centro de Avalição da Ilha da Marambaia (CADIM - Marinha do Brasil) for allowing this research and providing information and infrastructure.

\section{Conflicts of interest}

The authors declare no conflicts of interest.

\section{Author contribution statement}

We thank the reviewer for the corrections and improvements. Only, at the end of the methodology, we prefer to keep the explanation of how the original figures were redrawn and some were drawn from the types themselves.

\section{References}

Felt, E. P., 1907. New species of Cecidomyiidae. N. Y. Bull. 110, 97-165. Gagné, R., 1994. The Gall Midges of the Neotropical Region. Cornell University Press, Ithaca, 352 pp.

Gagné, R. J., Jaschhof, M., 2017. A Catalog of the Cecidomyiidae (Diptera) of the World. 4th ed. Entomological Society of Washington, Washington, $762 \mathrm{pp}$. Digital version.

Gagné, R. J., Posada, F., Gil, Z. N., 2004. A new species of Bruggmanniella (Diptera, Cecidomyiidae) aborting young fruit of avocado, Persea americana (Lauraceae), in Colombia and Costa Rica. Proc. Entomol. Soc. Wash. 106 (3), 547-553. 
Garrett, R., Romanos, M. T. V., Borges, R. M., Santos, M. G., Rocha, L., Silva, A. J. R., 2012. Antiherpetic activity of a flavonoid fraction from Ocotea notata leaves. Braz. J. Pharmacognosy. 22 (2), 306-313.

Goldenberg, R., 2013. Miconia. In: Jardim Botânico do Rio de Janeiro (Ed.), Lista de espécies da flora do Brasil. JBRJ, Rio de Janeiro. Available in: http://floradobrasil.jbrj.gov.br/jabot/floradobrasil/ FB9773 (accessed 04 March 2018).

Jardim Botânico do Rio de Janeiro, 2018. Flora do Brasil 2020 em construção. JBRJ, Rio de Janeiro. Available in: http://floradobrasil. jbrj.gov.br/ (accessed 04 March 2018).

Maia, V.C., 1999. Descrição de imaturos de quatro espécies de Asphonyliini neotropicais e nota taxonômica sobre Asphondylia maytenuse Maia \& Couri (Diptera, Cecidomyiidae). Rev. Bras. Zool. 16 (3), 775-778.

Maia, V. C., 2001. New genera and species of gall midges (Diptera, Cecidomyiidae) from three restingas of Rio de Janeiro State, Brazil. Rev. Bras. Zool. 18 (Suppl.1), 1-32.

Maia, V. C., Couri, M. S., Monteiro, R. F., 1992. Sobre seis espécies de Asphondylia Loew, 1850 do Brasil (Diptera, Cecidomyiidae). Rev. Bras. Entomol. 36 (3), 653-661.

Maia, V. C., Fernandes, G. W., Oliveira, L. A., 2010. A new species of Bruggmanniella (Diptera, Cecidomyiidae, Asphondyliini) associated with Doliocarpus dentatus (Dilleniaceae) in Brazil. Rev. Bras. Entomol. 54 (2), 225-228.

Möhn, E., 1961. Neue Asphondyliidi-Gattungen (Diptera, Itonididae). Stuttgarter Beitr. Naturkunde. 49, 1-14.
Möhn, E., 1963. Studien üben neotropische Gallmücken (Diptera, Itonididae). 1. Teil. (Fortsetzung). Brotéria. Ser. Cienc. Naturais. 32, 3-23.

Paulino, R. C., Henriques, G. P. S. A., Coelho, M. F. B., Maia, S. S. S., Azevedo, R. A. B., 2011. Contribuição ao conhecimento e conservação da laranjinha. Interações 12 (2), 215-223.

Quinet, A., Baitello, J. B., Moraes, P. L. R., Alves, F. M., Assis, L., 2013. Lauraceae. In: Jardim Botânico do Rio de Janeiro (Ed.), Lista de espécies da flora do Brasil. JBRJ, Rio de Janeiro. Available in: http:// floradobrasil.jbrj.gov.br/jabot/floradobrasil/FB8473 (accessed 04 March 2018).

Silva, K. B., Alves, E. U., Bruno, R. L. A., Matos, V. P., 2012. Caracterização morfológica de frutos, sementes e germinação de Sideroxylon obtusifolium (Roem. e Schult.) Penn. (Sapotaceae). Rev. Arvore Vicosa-MG. 36 (1), 59-64.

Tavares, J. S., 1909. Contributio prima ed cognitionem cecidologiae Braziliae. Brotéria. Ser. Zoologica. 8, 5-28. [pls. I - VIII; Braga.]

Tavares, J. S., 1920. O género Bruggmanniella Tav. Com a descripção de uma espécie nova e a clave dichotómicados géneros das Asphondyliariae. Brotéria. Ser. Zoologica. 18, 33-42.

Tokuda, M., Yukawa, J., 2006. First records of genus Bruggmanniella (Diptera: Cecidomyiidae: Asphondyliini) from Palearctic and Oriental regions, with descriptions of two new species that induce stem galls on Lauraceae in Japan. Ann. Entomol. Soc. Am. 99, 629-637.

Urso-Guimarães, M. V., Amorim, D. S., 2004. Two new species of Bruggmanniella Tavares 1909 (Diptera, Cecidomyiidae) from Brazil. Stud. Dipterologica 11, 429-436. 